\title{
Perspectives from India on geoengineering
}

\author{
Vikram Mathur and Aparna Roy*
}

Geo-engineering technologies for deliberate and large-scale manipulation of the Earth's climate system are receiving serious scientific and political interest in the discourse on policy instruments for limiting temperature rise to $1.5^{\circ} \mathrm{C}$. While the debate on the scientific and technical feasibility of a range of geo-engineering technologies rages on, there is an urgent need for analysis of the complex ethical, social and governance issues related to research, experimentation and eventual deployment of these technologies. Our perception survey of Indian policy makers dealing with climate change has identified a number of governance concerns related to geoengineering technologies. Possible unintended consequences and 'side effects' of these technologies raises concerns of differential impacts in the vulnerable global south. Large-scale deployment of BECCS could have significant impact on food security, water resources and biodiversity. Above all, Indian policy makers are concerned about the prospect of unilateral action on geoengineering by developed nations. We examine in this article potential governance arrangements for geo-engineering technologies.

Keywords: Climate change, geoenginering, governance, perspective.

INDIA's climate research and policy community widely supports the Paris Agreement which aims to limit increase in global average temperatures to well below $2^{\circ} \mathrm{C}$, and to pursue efforts to limit the temperature rise to $1.5^{\circ} \mathrm{C}$ by 2100 compared to pre-industrial levels ${ }^{1}$. Yet, what is less well known in India and elsewhere is that the mitigation scenarios in integrated assessment models (IAMs) published by the Intergovernmental Panel on Climate Change (IPCC), which form the evidence basis of global climate policy, built on unproven negative emission technologies to achieve these temperature goals ${ }^{2}$. At the current rate of annual global $\mathrm{CO}_{2}$ emissions, the budget for $1.5^{\circ} \mathrm{C}$ is estimated to be consumed as early as the $2020 \mathrm{~s}$, while the 2030s would see humanity blow through the $2^{\circ} \mathrm{C} \mathrm{budget}^{3}$. Given that a complete decarbonation of the global economy within 10-20 years is highly unlikely, the implicit assumption in IPCC's Fifth Assessment Report is that negative carbon emission technologies cannot be avoided if temperature targets are to be taken seriously ${ }^{4}$. The negative emission technologies used in the IAMs of IPCC's Fifth Assessment Report are in the form of bioenergy with carbon capture and storage (BECCS) ${ }^{5}$. The mitigation scenarios assume large-scale deployment of BECCS over the course of the 21 st century to keep the $2^{\circ} \mathrm{C}$ target within reach. However, BECCS is a technically untested technology with only one demonstration plant currently in operation in the world today ${ }^{2}$.

Vikram Mathur and Aparna Roy are with the Observer Research Foundation, 20, Rouse Avenue Institutional Area, New Delhi 110 002, India. *For correspondence. (e-mail: aparna@orfonline.org)
BECCS is part of a larger suite of 'geoengineering' technologies which are designed for 'deliberate and large-scale manipulation of the Earth's climate system, and which are receiving serious levels of scientific and political attention. There are two main types of geoengineering technologies - those involving carbon dioxide $\left(\mathrm{CO}_{2}\right)$ removal (CDR), i.e. negative emissions, and those that aim to reflect a part of the sunlight and heat received on earth back into space, through solar radiation management (SRM) ${ }^{6}$. CDR techniques include the aforementioned BECCS as well as proposals to fertilize the oceans to increase algal growth that will remove more $\mathrm{CO}_{2}$ from the atmosphere, or direct capture of $\mathrm{CO}_{2}$ from the air ${ }^{6}$. SRM includes a wide array of techniques, including surface albedo approaches, i.e. making surfaces brighter to reflect sunlight back; space-based techniques such as giant reflectors placed near earth orbits; or the most commonly discussed method of stratospheric aerosols, wherein a wide range of particles (such as sulphate aerosols) could be released into the stratosphere with the aim of scattering sunlight back into space ${ }^{6}$. Although both CDR and SRM have the ultimate aim of reducing global temperatures, they operate differently and through different modes of action and on different timescales. Table 1 provides summary of some common types of geoengineering technologies and their attributes ${ }^{7-11}$.

The concept of geoengineering was reintroduced in climate debates in 2006 by the Noble Prize-winning scientist Paul Crutzens ${ }^{12}$, who argued that it was the only remaining solution in the face of societal failures to implement adequate mitigation efforts in order to fight 
GENERAL ARTICLES

Table 1. Commonly proposed geoengineering technologies and their attributes

\begin{tabular}{|c|c|c|c|c|}
\hline $\begin{array}{l}\text { Type of } \\
\text { geoengineering }\end{array}$ & $\begin{array}{c}\text { Technology } / \text { method } \\
\text { proposed }\end{array}$ & $\begin{array}{c}\text { Proposed } \\
\text { effects/actions }\end{array}$ & $\begin{array}{l}\text { Risks/potential } \\
\text { side effects }\end{array}$ & $\begin{array}{c}\text { Feasibility/ } \\
\text { cost/effectiveness }\end{array}$ \\
\hline \multirow[t]{5}{*}{$\begin{array}{l}\text { Carbon dioxide }\left(\mathrm{CO}_{2}\right) \\
\text { removal }\end{array}$} & Land use management ${ }^{1, *}$ & $\begin{array}{l}\text { Afforestation, reforestation } \\
\text { and avoided deforestation to } \\
\text { limit } \mathrm{CO}_{2} \text { emissions from } \\
\text { land-use change. }\end{array}$ & $\begin{array}{l}\text { Limited side effects, but could } \\
\text { lead to land-use conflicts } \\
\text { and biodiversity } \\
\text { implications }{ }^{6} \text {. }\end{array}$ & $\begin{array}{l}\text { High feasibility, low cost, } \\
\text { but limited impact } \\
\text { on global } \mathrm{CO}_{2} \\
\text { emissions }{ }^{6} \text {. }\end{array}$ \\
\hline & $\begin{array}{l}\text { Bio-energy with carbon } \\
\text { capture and storage } \\
\text { (BECCS) }\end{array}$ & $\begin{array}{l}\text { Biomass harvested and used as } \\
\text { fuel in plants which capture } \\
\text { and sequester the carbon } \\
\text { released, thereby leading } \\
\text { to net negative emissions. }\end{array}$ & $\begin{array}{l}\text { Potential land-use conflicts over } \\
\text { whether land should be used } \\
\text { for food or growth of fuel for } \\
\text { negative-emission power } \\
\text { plants }{ }^{6} \text {. }\end{array}$ & $\begin{array}{l}\text { No feasibility } \\
\text { demonstrated at the } \\
\text { global level. Expensive } \\
\text { compared to other } \\
\text { mitigation options }{ }^{2,6} \text {. } \\
\text { Significant potential for } \\
\text { impact on global } \\
\text { emissions. }\end{array}$ \\
\hline & Direct $\mathrm{CO}_{2}$ capture & $\begin{array}{l}\text { Industrial process that captures } \\
\mathrm{CO}_{2} \text { from ambient air for a } \\
\text { pure } \mathrm{CO}_{2} \text { stream for disposal } \\
\text { or use }{ }^{6} .\end{array}$ & Minimal & $\begin{array}{l}\text { High technical feasibility, } \\
\text { but costs are uncertain } \\
\text { and potentially high. } \\
\text { Large potential impact. }\end{array}$ \\
\hline & Fertilization of the oceans & $\begin{array}{l}\text { Increased rate of } \mathrm{CO}_{2} \\
\text { absorption by oceans by } \\
\text { promoting algae growth } \\
\text { through introduction of } \\
\text { nitrogen or iron. }\end{array}$ & $\begin{array}{l}\text { High potential for adverse } \\
\text { side effects as it involves } \\
\text { changing the marine } \\
\text { ecosystem } 6 .\end{array}$ & $\begin{array}{l}\text { Feasible, but not } \\
\text { cost-effective. Modest } \\
\text { impact on global } \\
\text { emissions and slow to } \\
\text { reduce global } \\
\text { temperatures } \\
\text { tem. }\end{array}$ \\
\hline & Accelerated weathering & $\begin{array}{l}\text { Silicate rocks that absorb } \\
\mathrm{CO}_{2} \text { naturally are pulverized } \\
\text { and spread on terrestrial } \\
\text { landscapes to increase their } \\
\text { surface area and increase the } \\
\text { rate of } \mathrm{CO}_{2} \text { absorption }\end{array}$ & $\begin{array}{l}\text { Potential respiratory health } \\
\text { impacts from production } \\
\text { and dispersal of pulverized } \\
\text { rocks } 9 .\end{array}$ & $\begin{array}{l}\text { Could be combined with } \\
\text { crop production, making } \\
\text { it a feasible option at scale. } \\
\text { High costs estimated } \\
\text { to be in trillions of } \\
\text { US dollars for mining, } \\
\text { grinding and transport } \\
\text { of minerals to site } 9 \text {. }\end{array}$ \\
\hline \multirow[t]{4}{*}{$\begin{array}{r}\text { Solar radiation } \\
\text { management }\end{array}$} & $\begin{array}{l}\text { Stratospheric aerosol } \\
\text { injection }\end{array}$ & $\begin{array}{l}\text { Injection of aerosols into the } \\
\text { atmosphere for scattering } \\
\text { sunlight back into space, } \\
\text { cooling temperatures and } \\
\text { mimicking the effect of a } \\
\text { volcano eruption } 6 .\end{array}$ & $\begin{array}{l}\text { Possible effects on hydrological } \\
\text { cycle, regional climate, } \\
\text { biological productivity, } \\
\text { and stratospheric ozone }\end{array}$ & $\begin{array}{l}\text { Feasible and potentially } \\
\text { highly effective to } \\
\text { reduce temperatures, but } \\
\text { no impact on carbon } \\
\text { emissions or ocean } \\
\text { acidification. Likely to } \\
\text { be highly affordable }\end{array}$ \\
\hline & Marine cloud brightening & $\begin{array}{l}\text { Seeding of marine clouds } \\
\text { with sea-water aerosols to } \\
\text { increase the cloud droplet } \\
\text { number concentration, which } \\
\text { can create a negative forcing } \\
\text { to balance the positive forcing } \\
\text { from } \mathrm{CO}_{2} \text { (ref. 10). }\end{array}$ & $\begin{array}{l}\text { Potential impacts on } \\
\text { precipitation patterns with } \\
\text { reductions in global } \\
\text { average rainfall estimated }{ }^{11} \text {. }\end{array}$ & $\begin{array}{l}\text { Low to medium costs and } \\
\text { feasible at scale, but no } \\
\text { impact on ocean } \\
\text { acidification or } \\
\text { stratospheric climate } \\
\text { change from increasing } \\
\text { levels of } \mathrm{CO}_{2} \text { (ref. 11). }\end{array}$ \\
\hline & $\begin{array}{l}\text { Giant shields/deflectors } \\
\text { in the outer space }\end{array}$ & $\begin{array}{l}\text { Reflective material or mirrors } \\
\text { placed in a near-earth orbit } \\
\text { which can deflect sunlight } \\
\text { away from the earth. }\end{array}$ & $\begin{array}{l}\text { Regional climate effects } \\
\text { likely, particularly on } \\
\text { hydrological cycle }^{6} .\end{array}$ & $\begin{array}{l}\text { High capital costs and long } \\
\text { timelines for } \\
\text { installation. Could } \\
\text { reduce temperatures } \\
\text { within a few years, but } \\
\text { no impact on carbon } \\
\text { emissions or ocean } \\
\text { acidification. }\end{array}$ \\
\hline & $\begin{array}{l}\text { Surface albedo } \\
\text { approaches }\end{array}$ & $\begin{array}{l}\text { Painting roofs of buildings } \\
\text { bright white; installing desert } \\
\text { reflectors in subtropical } \\
\text { countries to reflect sunlight } \\
\text { away from the ground }{ }^{6,7} \text {. }\end{array}$ & $\begin{array}{l}\text { Minimal for painting; high for } \\
\text { desert albedo approaches as } \\
\text { it could involve major effects } \\
\text { on desert ecosystems and } \\
\text { local rainfall patterns }{ }^{6} \text {. }\end{array}$ & $\begin{array}{l}\text { Could take several decades } \\
\text { for sufficient action and } \\
\text { not enough settlement } \\
\text { area to be effective in } \\
\text { case of surface } \\
\text { brightening }{ }^{6} \text {. High costs } \\
\text { of labour and } \\
\text { maintenance for both, } \\
\text { and no impact on carbon } \\
\text { emissions or ocean } \\
\text { acidification. }\end{array}$ \\
\hline
\end{tabular}

*Land use management is sometimes not considered geoengineering, but has been included here in line with the definitions used by the Royal Society Report on Geoengineering the Climate ${ }^{6}$. 
climate change. While geoengineering in the form of negative emissions has since been implicit in the policy conversation for the $2^{\circ} \mathrm{C}$ target due to the IPCC models assuming large-scale deployment of BECCS as highlighted, the ambition of climate policy to aim for $1.5^{\circ} \mathrm{C}$ as a result of the Paris Agreement has also brought solar geoengineering (or SRM) into the spotlight. The impending withdrawal of USA from the Paris Agreement casts significant doubt over global carbon reduction targets. Serious efforts to limit temperature rise to $1.5^{\circ} \mathrm{C}$ are therefore likely to require deployment of solar geoengineering ${ }^{13}$.

Over the last few years, prominent scientific bodies, including the US National Academy of Sciences and the Royal Society of London have called for geoengineering research. Most recently, a group of scientists at Harvard University, USA have launched the world's biggest solar geoengineering field study - a 20 million USD programme that will send aerosol injections $20 \mathrm{~km}$ up into earth's atmosphere to examine the effects of aerosols on stratospheric chemistry ${ }^{14}$.

The first particles are expected to go up into the atmosphere by 2022. These developments have caused alarm in India and elsewhere about the side effects of such technologies and unilateral experimentation and testing. Therefore, while a debate on the scientific and technical feasibility of a range of geoengineering technologies is urgently needed ${ }^{4,13}$, there is also a need for the analysis of complex ethical, social, governance, and public perception issues related to research, experimentation and eventual deployment of these technologies.

A recent study, for instance, has examined public perception and acceptance of SRM technologies in Canada, China, Germany, Switzerland, UK and USA ${ }^{15}$. A majority of the technical and social research on geoengineering is being done in a select few developed countries, particularly USA, UK and Germany. Perspectives from the Global South are almost entirely missing.

In this article we discuss the perspectives of policymakers and experts in the country dealing with climate change to understand the emerging Indian views on geoengineering methods and the governance of their research and potential deployment. India, as the world's third largest carbon emitter with a high exposure to climate vulnerability, is an important player in climate policy. In recent years, it has begun to move from the fringes of global climate policy to being an principal actor shaping global efforts ${ }^{16}$. However, Indian perspectives on geoengineering remain largely unarticulated, although discussions regarding the field with ministerial involvement have begun in the past year in the country ${ }^{17}$. Several institutions in India have also undertaken a significant volume of work in modelling geoengineering techniques ${ }^{18-20}$.

To gather Indian views on geoengineering we conducted semi-structured, ethnographic interviews with a wide array of stakeholders (Appendix 1) in the Indian climate policy community $^{21}$, including policymakers, pri- vate-sector actors and civil society, to understand their perceptions. Sampling for these interviews was nonrandom, also described as purposeful sampling ${ }^{22}$.

\section{Indian perspectives on geoengineering}

Conversations with the Indian climate policy community threw up a traditional set of arguments, which we have discussed around six key themes: (i) disturbing the 'natural balance' and playing God; (ii) moral hazard - not weaning economies off carbon, particularly in developed economies hoping for a technical fix; (iii) uncertainty about both the effectiveness of the technologies and their potential unintended consequences; (iv) fear of unilateral action and possible weaponization by rouge states; (v) public participation, transparency, disclosure and sharing of information, and (vi) complex governance concerns over jurisdiction and scale.

\section{Natural balance}

Many policymakers as well as actors from civil society have a visceral distaste and revulsion to the very idea of geoengineering - they see it as crude and arrogant 'human interference with the natural world' - a world that is fragile and complex in ways that humans cannot see. The environmental movement in India, conceptualizes nature as God's domain - drawing a line between what is 'natural' and 'artificial'. Comparisons are drawn between geoengineering and the debates over genetically modified crops (GMOs). Many respondents see blurring of this line and extending human boundaries of influence to manipulate nature as a matter of great concern, as it might lead to adverse consequences. One respondent for instance says: '...trying to control earth's thermostat and injecting sulphate aerosols into the atmosphere will be invading the domain of "nature" to serve our purpose. This might ultimately lead to unforeseeable, irreversible and dangerous consequences.'

Incidentally, this framing of geoengineering as a question of 'natural balance' is not uncommon, and has been studied by Huttunen and Hildén ${ }^{23}$ who identify three distinct frames of how geoengineering is presented in the literature, namely risk-benefit, governance and natural balance. Articles in the frame of 'natural balance' present geoengineering as an ethical question which does not solve the original problem of climate change, but adds more problems - the moral judgement is that geoengineering is immoral and a distortion of the human-nature relationship ${ }^{23}$.

\section{Moral hazard}

Across the board, all respondents - from policymakers to scientists - share the concern that efforts around 
geoengineering may reduce incentives to wean economies off carbon and also pursue serious efforts to build resilience to climate change. This perception of geoengineering as a 'moral hazard' has been noted before in debates over the ethics of geoengineering - will the discussion of a potential 'get out of jail' free card for climate change mean a diminishing of political will to undertake drastic mitigation to reduce anthropogenic carbon emissions? ?,24,25 $^{6,24}$

According to one respondent, 'development of any such (geoengineering) technology would mean accepting that global emission reduction strategies have failed so we now need to work on an alternative plan to save the world from the catastrophic effect of climate change'. This is particularly problematic because we do not in fact know if these technologies actually work - but research, experimentation and build-up may reduce the urgency with which mitigation strategies are pursued by developed nations locked into high fossil-fuel use. A potential techno-fix to climate problems will create disincentives for governments to take the hard decisions about transitions to lower carbon trajectories. Research funding and R\&D efforts for clean energy or drought-resistant agriculture may be instead diverted to geoengineering. Furthermore, developed nations might not just weaken their mitigation efforts, but also diminish their commitment under the Paris Agreement to supporting low carbon growth, adaptation and climate-resilient development in the developing nations. This is also noted as worrying, because geoengineering is by no means a final solution to climate change and instead may create dangerous dependencies, if pursued as a sole response to global warming.

Respondents also feel that 'research and development of geoengineering might set a "slippery slope" until deployment', if risks are not carefully considered in the early stages of research.

\section{Uncertainty and unintended consequences}

Respondents expressed concerns over the uncertain risks of geoengineering technologies. They feel that the ignorance or a lack of adequate knowledge and understanding of the various impacts that geoengineering may have on the environment, economy and society, is worrisome. Possible unintended consequences and side effects of these technologies raise concerns of differential impacts in the vulnerable Global South. For instance, respondents note that tropical areas will likely be favoured for rapid large-scale cultivation of crops under BECCS, thereby competing with agricultural land. In the case of SRM, unforeseen impacts on rainfall patterns are cited as particularly damaging for the Global South given the dependence on agriculture in several developing country economies, including India.

Policymakers also caution that in the absence of accuracy in prediction and knowledge of probabilities, appli- cation of geoengineering technologies might add to the complexity of climate instability, rather than solving the problem.

Some of the respondents, however, acknowledge that many fears around uncertain risks could only be mitigated through research and demonstration, and accordingly, advocate for wider engagements in the field. Given that the technology is still in its infancy, some respondents argue that this may provide more opportunity of influencing its social, political and innovation trajectories. Once the technology matures and is set closer to deployment, the risk of losing control over possible safeguards considerably increases. Naturally, this possibility depends on the governance frameworks designed for geoengineering research.

\section{Fear of unilateral action}

Respondents in India feel threatened by the possibility of unilateral action by countries on geoengineering. Their concern is that at some point in future, with accelerated climate change and unsuccessful global efforts to address the negative impacts of global warming such as rising sea levels, disruptions to agriculture and altered precipitation patterns, a country with geoengineering technology at its disposal might use it as a climate intervention strategy to suit its interest.

This is particularly concerning as some forms of geoengineering require little global support and can be easily deployed by a nation acting independently. As a respondent noted during the interview: 'the cost of geoengineering is trivial and any developed country can afford it. Without an international agreement, it will be possible for any country suffering from climate extremes to act on its own on geoengineering'.

Such unilateral action might create winners and losers. Unilateral deployment, according to Indian stakeholders, may allow a country to seize control over the global thermostat, violate consensus among the international community, cause negative impacts over some states and regions, and even offend countries that view human intervention on the climate as 'unnatural'. Respondents fear that this might even impact geo-political peace and stability and trigger an extreme international response like sanction or climate war.

\section{Engagement and participation}

The majority of researchers argue that research and testing of geoengineering might unevenly impact different regions of the world. To counter secrecy during research, respondents advocate for research and experimentation to be done in a transparent and inclusive manner. This should include wider participation of the public, policymakers and civil society, along with the scientific community. 
The fact that much of the research capacity rests among scientists in the developed countries is of serious concern for Indian policymakers, who fear that scientific edge will eventually lead to political advantage in terms of determining the direction of research and setting up governance frameworks. Respondents have suggested that international research bodies might engage with research institutions in India as well as other developing countries, to do mapping and test the applicability and impact of technologies in local conditions. Financing these research projects through grants can help develop local research capacities.

\section{Governance}

What is the optimal and feasible level of control of research and experimentation through governance arrangements to avoid laissez-faire deployment? The climate research and policy community in India tabled several options - ranging from total control of all geoengineering research and experimentation under the intergovernmental The United Nations Framework Convention on Climate Change (UNFCCC), moratorium of certain SRM technologies such as stratospheric aerosol injection (SAI), to more decentralized bottom-up approaches.

Many felt that UNFCCC was too narrow in its focus; geoengineering has complex aspects in terms of technology, its deployment and impact, with potential linkages to other global regimes. Rising controversies over moral hazard, fear of unilateral action, and geo-political issues, may in fact weaken the climate policy solidarity under UNFCCC.

In terms of jurisdiction, geoengineering technologies are likely to fall under two categories - (i) international regimes governing global commons (land, atmosphere and oceans), and (ii) national territorial projects. SRM projects like space mirrors resulting in cloud whitening are an atmospheric intervention, which may fall under international regimes. Initiatives like roof surface albedo approaches and afforestation could fall under national jurisdiction.

The risk of potentially harmful effects at a global scale of many of the geoengineering technologies may need to be controlled through other international treaties and laws. Respondents have cited the International Maritime Organization (IMO) governing maritime navigation and protection of the marine environment, Convention on the Prohibition of Military or Any Other Hostile Use of Environmental Modification Techniques (ENMOD), and Montreal Protocol on Substances that Deplete the Ozone Layer, as few of the existing frameworks.

\section{Governance of geoengineering}

Governance of research, experimentation and potential deployment of geoengineering technologies will need to respond to complex ethical and technical challenges that concern policy actors in India and elsewhere. The literature on governance of geoengineering is limited, but is emerging. For example, Rayner et $a .^{26}$ put forward the 'Oxford Principles' which consist of five principles for governance, research, development and possible deployment of geoengineering technologies ${ }^{26}$. The principles call for geoengineering to be regulated as a public good; public participation in decision-making; open disclosure of results; independent assessment of impacts; and governance to be settled before deployment ${ }^{26}$. The Oxford Principles, however, do not dwell on the question of equity. Both the scientific and policy communities in India view certain technologies such as SAI negatively, because of the potential impact of these on precipitation patterns $^{27}$, which are particularly vital for lives and livelihoods in the Global South.

Fear of unilateral action on SAI must be countered through two strategies. First, transnational participation and representation in geoengineering research is crucial from the laboratory to publication of results and public assessment. Environmental science and modelling of global climate systems has typically been the domain of scientists from developed countries ${ }^{28-30}$. There is widespread concern among the Indian scientific and policy community that the emerging geoengineering discourse will continue in the same vein and be biased towards northern framings of risks, ethics and governance, despite the growing scientific knowledge on geoengineering in India and other developing countries. For instance, much of the discourse on solar geoengineering has already begun to call for research into such techniques in the service of equity ${ }^{31}$, invoking the argument that climate impacts will disproportionately affect poorer countries and therefore constitute a moral obligation to pursue research that could limit these impacts. Such literature casts developing countries in the role of what Jasanoff ${ }^{32}$ has termed 'passive agents in the path of potentially disastrous events', and is inimical to inclusive conversations and research around geoengineering that treat developing countries as equal partners in managing the global climate.

A national experiment such as the one conducted in Russia in 2008, as well as the recently launched privately funded experiment on solar geoengineering at Harvard University which has no cross-country representation is highly problematic. Scientific superiority will lead to political power: uneven scientific capacities will see promotion of the interests of richer nations. In the 20th century, such advantages led to 'carbon colonialism, ${ }^{33}$, as countries in the Global North industrialized on the back of dirty fossil fuels, limiting the space available for developing countries to do the same later without significantly aggravating global warming. It is vital that technological development of geoengineering technologies such as SAI does not perpetuate 20th century inequities. 
Successful examples of international research cooperation on large-scale technology programmes already exist. For instance, the International Thermonuclear Experimental Reactor (ITER) project, where several countries are working together to build a large nuclear fusion reactor, is an excellent example of cross-country collaboration. In the absence of coordinated research programmes, sharing and open publication of results can help enable transparency and trust. For instance, the idea of a 'data commons' has been suggested for solar geoengineering research which could ensure research data are available publicly and free of charge ${ }^{34}$. Research on SAI particularly can benefit from such models of scientific collaboration, and governance frameworks need to steer scientific inquiry towards such arrangements ${ }^{35}$.

Secondly, differentiation along the lines of technology in governance frameworks is also important and cannot be just restricted to differentiating between SRM and CDR. Rather, technologies need to be governed in line with the scale of their potential negative impacts on the global commons - oceans and atmosphere. As such, some approaches such as BECCS, land-use management and surface albedo techniques can be governed by states and national governments - 'bottom-up', like adaptation and mitigation action under the overall umbrella of the Paris Agreement. On the other hand, activities such as fertilization of the oceans, SAI, and giant shields in outer space will almost certainly require new governance frameworks. A new negotiated protocol under the UNFCCC for instance, to cover the potential deployment of these technologies should they prove technically feasible, could allow such decisions to rest with the Conference of Parties (COP).

These two strategies will go some distance to ensure that fears of unilateral action on geoengineering are addressed. Governance frameworks will, however, also have to be equipped to deal with the perception in India and elsewhere that geoengineering presents a 'moral hazard' and may be a substitute for mitigation and adaptation action. Serious questions relating to the technical feasibility, social acceptability, side effects and scalability of geoengineering still need to be answered. Therefore, there needs to be articulation of a normative and policy position on geoengineering under the UNFCCC and in the process for the implementation of the Paris Agreement, that climate policy needs to rest on increasingly ambitious mitigation and adaptation action by all nations while allowing for research on the technical feasibility and governance options of geoengineering. Geoengineering should be seen as one (minor) part of a globally coordinated strategy to deal with climate change that rests on mitigation and adaptation efforts. An honest, frank conversation on the implications of temperature targets for geoengineering and the implicit assumptions of BECCS deployment in IPCC's climate science is in any case long overdue in the UNFCCC.
The governance challenges for geoengineering can be compared to other emerging and controversial technologies such as nanotechnology, genetically modified foods, and synthetic biology ${ }^{36}$. These technologies pose the classic technology control dilemma, i.e. potential problems with the technology can only be resolved through research, development and demonstration ${ }^{37}$. The complexity of the governance of geoengineering cannot simply be captured as a dichotomy between, a deterministic technological position - that the technologies will develop through their own internal technical logic as a oneway trajectory, outside social control - and the quixotic precautionary position posited by some stakeholders who advocate complete moratorium on research and experimentation on ethical and moral grounds. A more complex governance regime based on multiple mechanisms ranging from protocols under the UNFCCC, shared normative principles, codes of conduct for research, process for public disclosure and engagement, funding mechanisms, opportunities for international research collaborations and methods for monitoring will need to be devised along with levers for changing course and adapting governance based on evidence as it becomes available.

The field of science and technology studies more generally concerns itself with the question of iterative and interactive societal decision-making around complex technoscience characterized by indeterminacy and contradictory social certitudes ${ }^{38}$. For example, Guston ${ }^{39}$ has proposed 'anticipatory governance' as a framework to create capacity across institutions and society more broadly to be reflective about the normative underpinnings of diverse plausible future trajectories of technology and support engagement between the public and those who conduct research and frame the research agenda $^{39}$. Reflexive governance has been proposed as a framework to deal with the issues of uncertainty and doubt around emerging technologies-shaping governance in light of learning and feedback from steering strategies dynamically $^{40}$.

Governance of geoengineering, like climate, is likely to be a complex social process navigating norms, laws and politics and not simply an assessment of technical feasibility or economic costs. Technical and scientific research gets more funding than governance research - analysts

Appendix 1. List of Interviewees

\footnotetext{
Member, Prime Minister's Council on Climate Change

Senior Professor and IPCC author in a prominent Indian university

Environmental Officer in a private sector organization

Assistant Professor in a leading national university in social sciences

Research Associate in a leading Indian environmental think-tank

Emeritus Professor in a prominent Indian university

Associate Professor in a prominent Indian university

Environmental Officer in a private sector organization
} 
have argued that no deployment should happen till governance arrangements have been debated and are in place-therefore, social research is equally important. Geoengineering is unlikely to be a magic bullet for solving climate change, nor is there a magic bullet for governing the research, experimentation and potential deployment of geoengineering. It is a complex problem with no clear solution in sight, but a framework for muddling through reflexively.

1. UNFCCC V, Adoption of the Paris Agreement, I: Proposal by the President (Draft Decision), United Nations Office, Geneva, Switzerland, 2015.

2. Anderson, K. and Peters, G., The trouble with negative emissions. Science, 2016, 354, 182-183.

3. Peters, G., Should climate policy aim to avoid $2^{\circ} \mathrm{C}$ or to exceed $2^{\circ} \mathrm{C}$ ? Centre for International Climate Research (CICERO), 2017; http://www.cicero.uio.no/no/posts/klima/should-climate-policyaim-toavoid-2c-or-to-exceed-2c (accessed on 4 May 2017).

4. Geden, O. and Schäfer, S., Negative emissions: a challenge for climate policy, 2016, 1-4; https://www.ssoar.info/ssoar/bitstream/ handle/document/49822/ssoar-2016-geden_et_al-Negative_emissions a challenge for.pdf? sequence $=1$

5. IPCC, Climate Change 2014: Synthesis Report. Contribution of Working Groups I, II and III to the Fifth Assessment Report of the Intergovernmental Panel on Climate Change. Core Writing Team, Pachauri, R. K. and Meyer, L. A., 2014; doi:10.1017/CBO9781107415324.004

6. The Royal Society, Geoengineering the Climate, 2009.

7. Humphreys, D., Smoke and mirrors: some reflections on the science and politics of geoengineering. J. Environ. Dev., 2011, 20, $99-120$.

8. Minx, J. C., Lamb, W. F., Callaghan, M. W., Bornmann, L. and Fuss, S., Fast growing research on negative emissions. Environ. Res. Lett., 2017, 12(3), 035007.

9. Taylor, L. L. et al., Enhanced weathering strategies for stabilizing climate and averting ocean acidification. Nature Climate Change, $2011,6,402-406$.

10. Latham, J. et al., Marine cloud brightening. Philos. Trans. R. Soc., London, Ser. A, 2012, 370, 4217-4262.

11. Bala, G. et al., Albedo enhancement of marine clouds to counteract global warming: impacts on the hydrological cycle. Climate Dyn., 2011, 37, 915-931.

12. Crutzen, P. J., Albedo enhancement by stratospheric sulfur injections: A contribution to resolve a policy dilemma? Climatic Change, 2006, 77, 211-219.

13. Parker, A. and Geden, O., No fudging on geoengineering. Nature Geoscience, 2016, 9(12), 859 .

14. Neslen, A., US scientists launch world's biggest solar geoengineering study. The Guardian, 2017; https://www.theguardian.com/ environment/2017/mar/24/us-scientists-launchworlds-biggest-solargeoengineering-study (accessed on 1 June 2017).

15. Visschers, V. H. M., Shi, J., Siegrist, M. and Arvai, J., Beliefs and values explain international differences in perception of solar radiation management: insights from a cross-country survey. Climate Change, 2017, 142(3-4), 531-544; doi:10.1007/s10584-017-1970-8

16. Michaelowa, K. and Michaelowa, A., India as an emerging power in international climate negotiations. Climate Policy, 2012, 12, 575-590.

17. Bala, G. and Gupta, A., Geoengineering and India. Curr. Sci., 2017, 113(3), 376-377.

18. Modak, A. and Bala, G., Sensitivity of simulated climate to latitudinal distribution of solar insolation reduction in solar radiation management. Atmos. Chem. Phys., 2014, 14, 7769-7779.
19. Kalidindi, S., Bala, G., Modak, A. and Caldeira, K., Modeling of solar radiation management: a comparison of simulations using reduced solar constant and stratospheric sulphate aerosols. Climate Dyn., 2015, 44, 2909-2925.

20. Ghosh, S., Sharma, A., Arora, S. and Desouza, G., A geoengineering approach toward tackling tropical cyclones over the Bay of Bengal. Atmos. Sci. Lett., 2016, 17, 208-215.

21. Spradley, J. P., The Ethnographic Interview, Waveland Press, 2016; doi:10.1300/J004v08n02_05

22. Kuzel, A. J., In Doing Qualitative Research (eds Crabtree, B. F. and Miller, W. L.), Sage Publications, Thousand Oaks, CA, US, 1992, pp. 31-44.

23. Huttunen, S. and Hildén, M., Framing the controversial: geoengineering in academic literature. Sci. Commun., 2013, 36, 3-29.

24. Keith, D. W., Geoengineering the climate: history and prospect. Annu. Rev. Energy Environ., 2000, 25, 245-284.

25. Corner, A. and Pidgeon, N., Geoengineering the climate - the social and ethical implications. Environ. Sci. Policy Sustain. Dev., 2010, 52, 24-37.

26. Rayner, S. et al., The Oxford Principles. Climate Change, 2013, 121(3), 499-512.

27. Bala, G., Duffy, P. B. and Taylor, K. E., Impact of geoengineering schemes on the global hydrological cycle. Proc. Natl. Acad. Sci. USA, 2008, 105, 7664-7669.

28. Karlsson, S., Srebotnjak, T. and Gonzales, P., Understanding the North-South knowledge divide and its implications for policy: a quantitative analysis of the generation of scientific knowledge in the environmental sciences. Environ. Sci. Policy, 2007, 10, 668-684.

29. Kandlikar, M. and Sagar, A., Climate change research and analysis in India: an integrated assessment of a South-North divide. Global Environ. Change, 1999, 9, 119-138.

30. Blicharska, M. et al., Steps to overcome the North-South divide in research relevant to climate change policy and practice. Nature Climate Change, 2017, 7, 21-27.

31. Flegal, J. A. and Gupta, A., Evoking equity as a rationale for solar geoengineering research? Scrutinizing emerging expert visions of equity. Int. Environ. Agreements: Politics, Law Econ., 2018, 18(1), 45-61; doi:10.1007/s10784-017-9377-6

32. Jasanoff, S., Technologies of humility: citizen participation in governing science. Minerva, 2003, 41, 223-244.

33. Agarwal, A. and Narain, S., Global warming in an unequal world: A case of environmental colonialism. In Global Warming in an Unequal World: A Case of Environmental Colonialism, Centre for Science and Environment, 1991.

34. Reynolds, J. L., Contreras, J. L. and Sarnoff, J. D., Intellectual property policies for solar geoengineering. Wiley Interdiscip. Rev.: Climate Change, 2018; doi:10.1002/wcc.512

35. Ghosh, A., Environmental Institutions, International Research Programmes, and Lessons for Geoengineering Research. Geoengineering Our Climate Working Paper, 2014; https:// geoengineeringourclimate.com/2014/02/25/environmental-institutionsinternational-research-programmes-and-lessons-for-geoengineeringresearch-working-paper

36. Sarewitz, D., Not by experts alone. Nature, 2010, 466, 688.

37. Collingridge, D., The Social Control of Technology, Frances Pinter, 1982.

38. Irwin, A., In The Handbook of Science and Technology Studies (eds Hackett, E. J. et al.), MIT Press, 2008, No. 3.

39. Guston, D. H., Understanding 'anticipatory governance'. Soc. Stud. Sci., 2014, 44, 218-242.

40. Voß, J. P., Bauknecht, D. and Kemp, R., Reflexive Governance for Sustainable Development, Edward Elgar Publishing, 2006.

Received 26 February 2018; revised accepted 22 May 2018

doi: $10.18520 / \mathrm{cs} / \mathrm{v} 116 / \mathrm{i} 1 / 40-46$ 